\title{
ANALYSIS OF SMES CREDIT RESTRUCTURING POLICY IN ECONOMIC RECOVERY DURING THE COVID-19 PANDEMIC
}

\author{
Lussi Agustin ${ }^{1}$, Moh. Yusron Solikin ${ }^{2 *}$, Zunairoh $^{3}$ \\ ${ }^{1}$ Fakultas Ilmu Sosial dan Ilmu Politik, Universitas Airlangga \\ Email: lussi.agustin-2020@fisip.unair.ac.id \\ ${ }^{2}$ Fakultas Ekonomi dan Bisnis, Universitas Airlangga \\ Email: mohammad.yusron.olikhin-2018@pasca.unair.ac.id \\ ${ }^{3}$ Fakultas Ekonomi dan Bisnis, Universitas Surabaya \\ Email: zunairoh@staff.ubaya.ac.id \\ *penulis korespondensi
}

\begin{abstract}
ABSTRAK
Penelitian ini bertujuan untuk menganalisis seberapa maksimal proses kebijakan retrukturisasi Kredit UMKM dalam Pemulihan Ekonomi di Masa Pandemi Covid-19. Kondisi perekonomian global sedang mengalami goncangan hebat akibat mewabahnya Covid-19. Dampak dari pandemic ini sangat mempengaruhi segala aspek terutama pada kondisi Kesehatan dan perekonomian suatu negara, tidak terkecuali Indonesia. Secara keseluruhan, hampir semua sektor industry mengalami goncangan dan tidak terkecuali sektor UMKM. Maka dari itu dikeluarkanlah kebijakan retrukturisasi Kredit UMKM guna mendorong optimalisasi fungsi intermediasi pada perbankan dan menjaga stabilitas sistem keuangan serta mendukung pertumbuhan perekonomian. Program restrukturisasi kredit menjadi program dari OJK yang dapat diterapkan oleh perbankan kepada UMKM. Metode yang digunakan dalam penelitian ini adalah metode kualitatif dengan menggunakan studi empiris dari penelitian terdahulu serta peraturan-peraturan terkait dengan restrukturisasi kredit yang dikeluarkan oleh Otoritas Jasa Keuangan. Hasil penelitian ini menunjukkan bahwa implementasi kebijakan restrukturisai kredit bagi UMKM sudah berjalan dan digunakan oleh para pelaku UMKM. Kemudian berdasarkan implementasinya kebijakan ini merupakan kebijakan top-down dimana memerlukan banyak Lembaga untuk bekerja sama dan keputusan berasal dari Peraturan pemerintah baru di teruskan ke Lembaga-lembaga lain di bawahnya hingga informasinya sampai dan bisa dirasakan oleh para UMKM.
\end{abstract}

Kata Kunci: Implementation, Restructuring, SMEs

\begin{abstract}
This research aims to analyze the policy of restructuring SMEs Credit in Economic Recovery during the Covid-19 Pandemic. The global economy is experiencing severe shocks due to the outbreak of Covid-19. The impact of this pandemic greatly affects all aspects, especially on the health and economic condition of a country, not least Indonesia. Overall, almost all industry sectors are experiencing shocks and are no exception to the SMEs sector. Therefore, the policy of restructuring SMEs Credit was issued to encourage optimization of intermediation function in banking and maintain the financial system stability and support economic growth. Credit restructuring program becomes a program from OJK that can be applied by banks to SMEs. The method used in this research is a qualitative method using empirical studies from previous research as well as regulations related to credit restructuring issued by the Financial Services Authority. The results of this research show that the implementation of credit restructuring policy for SMEs is already running and used by SMEs. Then based on the difference in implementation of this policy is a top-down policy that requires many Institutions to cooperate and decisions derived from the new government regulations are forwarded to other institutions under it until the information reaches and can be felt by SMEs.
\end{abstract}

Keywords: Implementation, Restructuring, SMEs.

\section{INTRODUCTION}

In early 2020 the world's citizens were shocked by the news related to the emergence of a new virus, the coronavirus which was declared by virologists as a very deadly virus. Coronaviruses are a group of viruses derived from the sub-family orthocoronavirinae in the family Coronaviridae and the order Nidovirales. At first, the virus affected animals such as poultry and mammals but later developed in humans (Nasruddin and Haq 2020). In Indonesia alone, the number of Covid-19 
cases is still not controlled. Task Force data handling Covid-19 recorded the total cases of deaths due to Covid-19 in June 2021 reached 7,913 cases at once the highest since the pandemic hit Indonesia. Head of Data and Technology Task Force, Dewi Nur Aisyah said, the total number of deaths in June exceeded the previous record of death cases that occurred in January, which amounted to 7,860 cases. Previously, Task Force data showed a decrease in deaths from February to April. Deaths in February recorded 6,168 cases. A total of 4,692 people died in March. Then, in April, the Task Force recorded 4,663 cases of death. Dewi mentioned, one of the causes of the high number of deaths is influenced by the increasing number of active cases. He said active cases in June continued to increase every week. Based on the data presented, in the first week of June, the number of active cases of Covid-19 was recorded at 14,933 people. Then in the second week, there was an increase to 29,332 cases. In the third week the number of active cases to 64,966 cases (CNN 2021). The following is the number of increases in Covid-19 cases in June 2021.

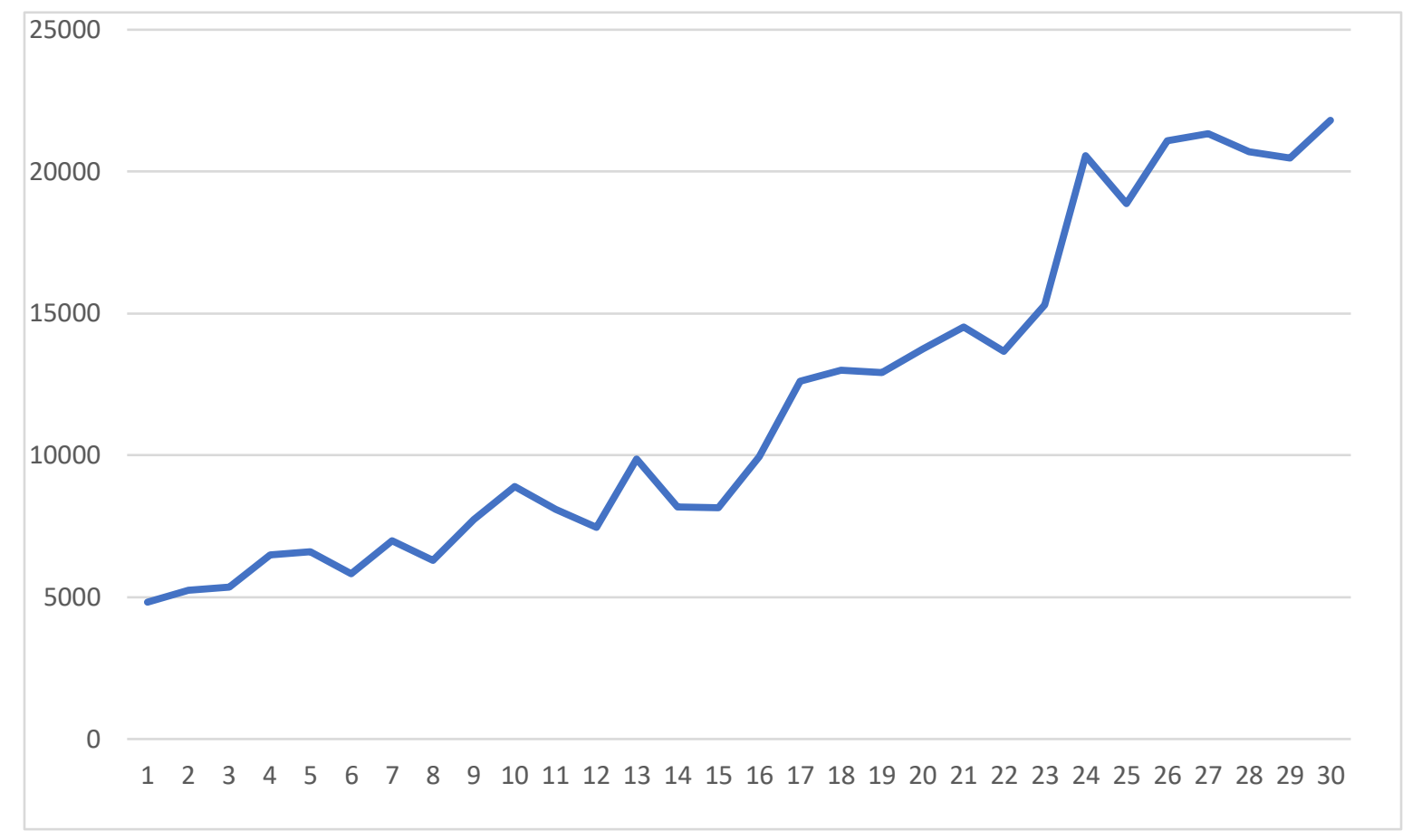

Figure 1. Addition of Covid-19 Cases in Indonesia June 2021

Source: covid19.go.id

Based on the increase in cases from July 3 to July 20, 2021, the Government will implement restrictions on emergency community activities (PPKM) in several areas. This policy was announced by President Joko Widodo through a YouTube broadcast of the Presidential Secretariat on Thursday, July 1, 2021. The target of implementing this emergency PPKM is to reduce daily confirmation cases of Covid-19 by less than 10,000 cases per day. Here are the rules of tightening community activities in the Emergency PPKM (Kompas 2021):

1. The non-essential sector implements 100 percent work from home (WFH)

2. All teaching and learning activities are conducted online or online

3. For the essential sector is enforced 50 percent maximum staff work from an office (WFO) with health protocols, and for critical staff allowed 100 percent maximum staff work from an office (WFO) with health protocols

4. Activities at shopping malls/malls/trading centers are closed 
5. The implementation of eating/drinking activities in public places (food stalls, restaurants, cafes, street vendors, hawkers) both in separate locations and located in shopping centers/malls only accept delivery or take away and do not accept on-site dining

6. Implementation of construction activities operates 100 percent by applying health protocols more strictly

7. Places of worship such as mosques, mosques, churches, temples, monasteries and temples and other public places that function as places of worship are temporarily closed

8. Public facilities (public areas, public parks, public tourist attractions, and other public areas) are temporarily closed

9. Cultural, sporting, and social art activities (location of art, culture. Sports facilities, and social activities that can cause crowds and crowds) are temporarily closed

10. Public transportation and rental vehicles are enforced with a maximum capacity setting of 70 percent by applying health protocols more strictly

11. The wedding reception is attended by a maximum of 30 people by applying health protocols more strictly and is not allowed to eat at the reception venue

12. Travelers using long-distance modes of transportation must present vaccine cards (minimum dose I) and PCR H-2 for aircraft as well as $\mathrm{H}-1$ antigens for long-distance modes of transportation

13. Masks are still worn when carrying out activities outside the home

14. Implementation of Micro PPKM in RT/RW red zone remains in place.

This policy has an impact on the economic sector, especially SMEs. According to Law No. 20 of 2008 concerning Micro, Small and Medium Enterprises (SMEs), mentioning that SMEs are small companies owned and managed by a person or owned by a small group of people with a certain amount of wealth and income. The micro-business itself is defined as a household business because most of its activities are done at home, using traditional or simple technology, hiring family members in the home, and oriented to the local market. Micro, small and medium enterprises (SMEs) are one of the main supporters of the economy, and the existence of SMEs can help create new jobs and increase the country's foreign exchange through taxation of business entities. Article 33 (4) of the 1945 Constitution affirms that small, medium, and micro-businesses are part of the national economy, independent-minded, and with great potential to improve the welfare of the community. Various efforts have been made by the government to increase the number of small, medium, and micro-businesses in each region. The government needs to play an incentive role for businesses by applicable regulations.

Based on the issue, the Financial Services Authority (OJK) issued POJK regulation No. 11/POJK.03/2020 on National Economic Stimulus as a Countercyclical Policy that stipulates that debtors or owners of credit obligations who get special behavior in POJK are debtors (including micro, small and medium enterprises) SMEs who have difficulty fulfilling obligations at banks (OJK) (OJK, 2020). This is because debtors are affected by the spread of Covid-19 either directly or indirectly in economic sectors, such as tourism, transportation, hospitality, trade, agriculture processing, and mining. Based on this research, this research will analyze the policy of restructuring SMEs credit in economic recovery during the Covid-19 pandemic which will be explained by the theory of Implications and Top-Down or Button Up Approach.

\section{LITERATURE REVIEW}

\section{Implementation Theory}

No literature specifically associates the basis of implementation with public policy ideas. That is in line with the view that public policy management should be considered the same as other activity 
management (Hill and Hupe 2002). Evidence of collective action is in the form of identifiable relics, such as inscriptions, pyramids, palaces, and so on. Much of the initial material implementation is associated with the explanation of the power of the rulers or the effectiveness of a democratic system. This historical record is widely written by those who have a dominant role or close relatives with such people. The success of the implementation can not be separated from the form of control or control carried out. The criteria for successful implementation in ancient times are also very simple. Implementation studies are also associated with the form of authority of Max Weber (Charismatic authority, traditional authority, and rational-legal authority).

Implementation Studies commenced in the Nineteen Seventies when Erwin Hargrove (1975) wrote about 'Missing Link' in the find out about of the coverage technique and Jeffrey Pressman and Aaron Wildavsky wrote a pretty influential e-book with the title Implementation (1973) (Wahab 2012). But it is plain that one-of-a-kind processes to implementation research did show up at the time. At that time there used to be a recognition that authorities' intervention to tackle a range of social issues was once growing rapidly, frequently ineffectively. This is a duration place there is giant boom and this is the beginning factor in research associated with coverage evaluation. Then, at that time additionally seemed the assumption made with the aid of the new college students of the implementation application that their topics had been abandoned. This then grew to become the historical past of political scientists started to use the notion of new implementation in coverage evaluation and administrative studies.

The simplest idea of democracy is to involve citizens in running the organization. Implicitly, direct democracy is the absence of divisions/conflicts between policy formation and its implementation. However, in its implementation, the organization still finds such circumstances. Therefore, there needs to be the development of an indirect representation approach to control the implementation. In an institutional economic perspective developed as a free context in which classical economics is analyzing market relations, it shows the importance of seeing these exchanges in structure with their rules by expected practices (Williamson 1975). In sociology, it raises various questions about the extent to which human actions are determined structurally. While in social sciences, organizations are formed because of the external environmental impacts that then form an informal social system that develops there. According to W.R Scott, there are three pillars of the institution: Regulative, relying on experience to recognize the coercive power of the rule system. Normative, based on social obligations. Then Cognitive, depending on existing cultural assumptions.

\section{Top-Down Approach}

Jeffrey Pressman and Aaron Wildavsky are known as the founders of implementation research. Part of their book's analysis is a research of an economic development plan endorsed by the Commonwealth of Oakland, California, that focuses on the extent to which implementation success depends on the relationship between different organizations and departments at the local level. They introduced a deficit implementation model that assumes that the success of implementation depends on the interrelationship between how organizations and departments at the local level are involved in the policy implementation process. Therefore, cooperation, coordination, and supervision become the focus of implementation. Implementation will fail if the cooperation relationship in the deficit chain. They assume that policies that rely on long-chain causality are easily hacked.

This model has a pessimistic tone in many implementation documents, as it shows that it is difficult to achieve action aimed at a large number of participants. However, Pressman and Wildavsky's original work did support a rational policy model approach that sets implementation research goals 
based on what considerations make achieving those goals difficult. If there is a comparison of experience between legislation and flexible implementation in its administrative system (such as the Italian administrative system), this model will be difficult to change.

Donald Van Meter and Carl Van Horn offer models for the analysis of the implementation process. According to Van Meter and Carl Van Horn, if marginal changes are embraced and consensus goals are high, then the implementation will be the most successful. According to both of them, the implementation of the policy about actions taken by individuals or groups (government or private) directed to achieve the objectives of the policy that has been set before (Horn and Meter. Donald Van 1975). They show that the effectiveness of implementation will vary greatly depending on the type of policy and the problem. According to them, conducting investigations should be done longitudinally. A relationship defined at one point should not extend casually over another period. Their approach is a top-down approach. The following is asserted that the six variables that affect the implementation of interrelated policies consist of two main variables and four variables, namely; Policy standards and objectives, implementation resources, relationships between organizations, characteristics of the implementing agent, social, economic, and political conditions, the last is the disposition of implementors.

\section{Bottom-Up Approach}

Michael Lipsky's analysis of the behaviour of frontline personnel is known as street bureaucracy and has a significant impact on the conduct of research. Michael Lipsky first proposed the idea in a paper in 1971, after his American counterparts, Pressman and Wildacsky, published his book. However, Lipsky's extensive work was not published until 1980 (Lipsky 2010). Faced with the pressures faced by the government, the decision-making process at the city level can encourage an ideal implementation process. At least some service promises. However, the nature of this work does not preclude them from approaching the ideal job idea. Large classes of workloads, insufficient resources, coupled with uncertain methods and uncertain customers, ignore the wishes or desires of service operators.

Benny Hjern is a Swedish scholar who developed research implementation methods while working on a European employment research and training project at a research institute in Berlin. Here's methodology is the fact that his colleagues making policy are learning depending on the interaction between several different organizations. It is worth noting that this issue is at the heart of Pressman as well as wildavsky's pioneering work. His theoretical approach, organizational sociological research, began to understand the fact that emphasizing the shape and boundaries of the organization would mislead the structure of the way people are. Establishing a working relationship without having to respect these restrictions. Thus, Hjern and his colleagues viewed the activity as a holistic structure formed in an organization and formed through a spontaneous self-selection process. The goal of Masmanian and Sabatier's exercises is to allow federal and state politicians to manage the administration efficiently. This is not intended to ensure effective implementation. In a previous discussion, the author concluded that the discussion of top-down and bottom up views turned into a comprehensive approach to selecting each key idea. The methodological elements of the argument itself will not cause controversy. The same goes for the discussion elements associated with understanding the most realistic implementation process.

\section{Previous Research}

Research from Rosyadi et al., (2021) aims to analyze the public policy obstacles that SMEs face in the creative economy at the local level. This research used qualitative case research methods and used purposeful sampling techniques to select insiders. The researchers collected data by 
interviewing 15 insiders. The informants include local government officials, SMEs, and creative economy activists. Analyze the data using thematic analysis in qualitative methods. This research shows that the development of SMEs in the creative economy is restricted by the thinking styles and administrative behaviors of local decision-makers, who are often normative, conventional, and inflexible. Therefore, the administrative capacity of local governments in the creative economy sector does not show significant support for efforts to improve the competitiveness of the creative economy at the regional level.

Pulka et al., (2021) discussed the moderate influence of the external environment on the relationship between entrepreneurial ability, entrepreneurial orientation, entrepreneurial network, government enterprise support, and SMEs performance. The purpose of this research is to use the resource-based view and dynamic capability theory to achieve. The results of this research show that entrepreneurial capability (EC), entrepreneurial orientation (EO), and government business support (GBS) directly affect the performance of SMEs. Surprisingly, the performance of SMEs is not affected by the entrepreneurship network (EN). Similarly, the external environment (EE) significantly regulates the relationship between EC, GBS, and SMEs performance. In contrast, EE has no moderate impact on the relationship between EO, EN, and SMEs performance.

Gyamerah et al., (2021) discuss whether East African small and medium-sized enterprises (SMEs) have benefited from the Belt and Road Initiative (BRI) and how the latter will affect the first internalization. This research used a qualitative method to interview 26 interviewees of SME managers/owners from countries along the "Belt and Road" who are engaged in international activities. The samples come from their industries in four East African countries. The theoretical framework is derived from the basic analysis of the main data theory. The results of this research show that the "Belt and Road" initiative, as a formal institutional force, has a direct or indirect impact on the internalization of SMEs. The three major driving forces of partnership, special services, and innovation support the internationalization of SMEs. In addition, the industry analysis of similarities and response differences shows that in the three industries surveyed, there is no significant difference between the driving factors and the impact of the "Belt and Road" initiative on SMEs.

Flynn \& Davis, (2016) aims to test the relationship between the company's experience in SMEfriendly policies (SMEs) and their participation and success in public procurement. In this research, variable bidding frequency, a success rate of public contract competition, and public sector-oriented business orientation are used. Using survey data from 2,755 SME respondents, the results of this research indicate that SME-friendly policies are explaining the success rate and business orientation of the sectoral market are of great significance. This is trivial in explaining the frequency of bidding. Then Nicholas \& Fruhmann, (2014), The reasons and effectiveness of support policies for SMEs in providing commodities and community procurement contracts will be considered. A set of economic reasons for SME policy comes from the view that awarding procurement contracts to SMEs to encourage innovation, entrepreneurship, etc. contributes to job creation, economic growth, and can support local and regional development and benefit the wider community the relationship between SMEs, innovation and economic growth is usually assumed in procurement contracts and community policymaking. Although some studies show that the growth rate of small companies is higher than that of large companies, other studies show that on the contrary, many micro and small enterprises, especially informal enterprises, are not actively trying to grow. There is also related research from (Natasya and Hardiningsih 2021), (Marlinah 2021), (Soleha 2020), (Novianggie 2021), and (Septriawan, Mulyani, and Iqbal 2021). 


\section{RESEARCH METHODS}

From the discussion that has been presented before, the method used in this research is the qualitative method whose findings are not obtained from statistical procedures. This research method was obtained because of a complex, dynamic, and meaningful social reality. This research describes a phenomenon that occurs fundamentally with the addition of several research procedures that contain descriptive data by reviewing a case that is at the heart of the problem. This research also relies on human religion as an important instrument in the resolution of research cases (Abdulllah and Saebani 2014).

This research emphasizes the results of written data obtained from field observations in the form of verbal observations or someone's behaviour in the form of words, pictures, and not in the form of words form or numbers that are more concerned with the subjective aspects of the behaviour being learned (Moleong 1989). Literature and empirical methods are classified as literature methods (Sukardi 2003). This research is descriptive, which according to Creswell \& Creswell, (2018) is a research method that seeks to explore and understand the meaning that several individuals or groups of people considered to be from social or humanitarian problems. Neuman further explained the objectives of descriptive research as follows:
a. Provide an accurate and detailed picture,
b. find new data that is contradictory to the old data that has been found before,
c. creating categorization or clarification of types,
d. explaining the series of steps or stages,
e. documenting due process or mechanism, and
f. provide a report on the background or context of the situation.

\section{RESULT AND DISCUSSION}

The result of the discussion in this research will explain a program of Covid-19 and the implementation of credit restructuring policy for SMEs based on implementation theory.

\section{Government Policy Related to Covid-19}

In the face of the Covid-19 pandemic, the Government has carried out several policies including PSBB, PPKM Mikro, Micro PPKM Thickening, and Emergency PPKM. Here's an explanation of each of these policies. Large-scale social restrictions (PSBB), this policy is the first coping strategy enacted at the beginning of the pandemic. A region can establish a PSBB as long as it qualifies, i.e. the number of cases and the number of Covid-19 deaths increases and spread significantly quickly and has to do with other regions. The policy mechanism, the governor/regent/mayor proposed the PSBB, the Minister set [agreements, and PSBB applied in the scope of certain regions (provinces, districts, or cities). PSBB consists of the involvement of colleges and workplaces, restrictions on non-secular activities, restrictions on things to do in public locations or facilities, restrictions on social and cultural activities, restrictions on modes of transportation, and restrictions on different activities, mainly associated with defense and protection aspects, solely indispensable sectors are allowed to function fully.

The enactment of Restrictions on Community Activities (PPKM) Java-Bali, after the Covid-19 case was considered quite controlled, the government then imposed a special PPKM policy only to the provinces in Java Bali, since January 11, 2021, for two weeks and was extended once. The region was chosen because it has high mobility and accounts for the largest number of positive cases of covid-19 compared to other regions. In the implementation of PPKM Jawa-Bali, work in the office can be applied by 75 percent with strict protocols, the habit of learning -teaching is done online, places of worship can be opened with a maximum capacity of 50 percent, then the essential 
sector can operate 100 percent with restrictions on operating hours and also visitors. Meanwhile, restaurants can only accept 25 percent of diners eating/drinking on the premises, shopping centers are limited to 19:00.

PPKM Mikro, after the Java-Bali PPKM was deemed no longer effective, the government imposed Micro PPKM, still in the same seven provinces. The difference is the strategy of handling PPKM Mikro based on community to the smallest unit at the RT / RW level. In MICRO PPKM, workers who work in the office are limited to 50 percent. Shopping malls or malls can operate until 21:00. Then, cotton stays eating in restaurants or dine-ins are limited to a maximum of 50 percent. Cottonistas of houses of worship is limited to a maximum of 50 percent.

Thickening of MICRO PPKM, after covid-19 cases surged after the Eid holiday in 2021, the government decided to implement a thickening of micro PPKM imposed for 14 days starting Tuesday, June 22, 2021. The policy includes the number of visitors in places to eat a maximum of 25 percent cottonistas, the number of workers maximum of 25 percent in offices located in red sona, and the prohibition of the operation of places of worship in the red zone. Similarly, schools in the red zone are prohibited from holding face-to-face learning. This strengthened Micro PPKM policy also involves environmental managers, village heads, lurah, village builders, and Bhayangkara Pembina Security and Public Order. Tightening is carried out to the smallest unit, RT / RW. For example, the level of neighboring pillars will be blocked if there are more than five houses whose residents are affected by covid-19.

PPKM Darurat, this policy was granted after the thickening of PPKM Mikro was considered insufficient to handle Covid-19 cases that continued to rise to penetrate the range of 20 thousand cases per day. Finally, President Jokowi decided to establish an Emergency PPKM. This policy is set in 48 regencies/cities with an assessment of pandemic situation level 4 and 74 regency/city with an assessment of pandemic situation level 3 on the islands of Java and Bali. This assessment level is assessed based on the rate of transmission and response capacity in an area according to WHO recommendations. Assessment levels 3 and 4 are areas that have high transmission, but the response of the area is relatively moderate to low. This area is considered to need special treatment through the Emergency PPKM policy. While the tightening of activity covers 100 percent work from home for the non-essential sector, then all teaching and learning activities are done online. For the essential sector, a maximum of 50 percent of work from the office staff is applied and for critical sectors, 100 percent work from the office is allowed.

Then for supermarkets, standard markets, grocery stores, and supermarkets that promote each day requirements are constrained to working hours till 20:00 nearby time with a traveler potential of 50 percent. Activities at buying malls/malls/trading facilities are closed; eating places and eating places solely receive the delivery/take away; Places of worship and public areas have been quickly closed. Travelers the usage of long-distance modes of transportation (planes, buses, and trains) should current a vaccine card (minimum dose I vaccine). Specifically for travel by plane mode, in addition to vaccine cards, passengers must also pocket the results of PCR swab tests with an H-2 time limit. While passengers for other long-distance modes of transportation, such as sea and land, can show antigen test documents with an A-1 time limit. (Amirullah 2021).

\section{Credit Restructuring Policy Analysis for SMEs}

In overcoming the economic crisis due to the Covid-19 pandemic. This situation is not left alone by the government, but rather issued Government Regulation No. 1 of 2020 governing national financial policy and financial system stability in the face of Covid-19. In addition, financial 
regulatory agencies and other institutions that have been puzzled have also published policies that support the perpu. Here are the key points in Perppu and related policies in question:

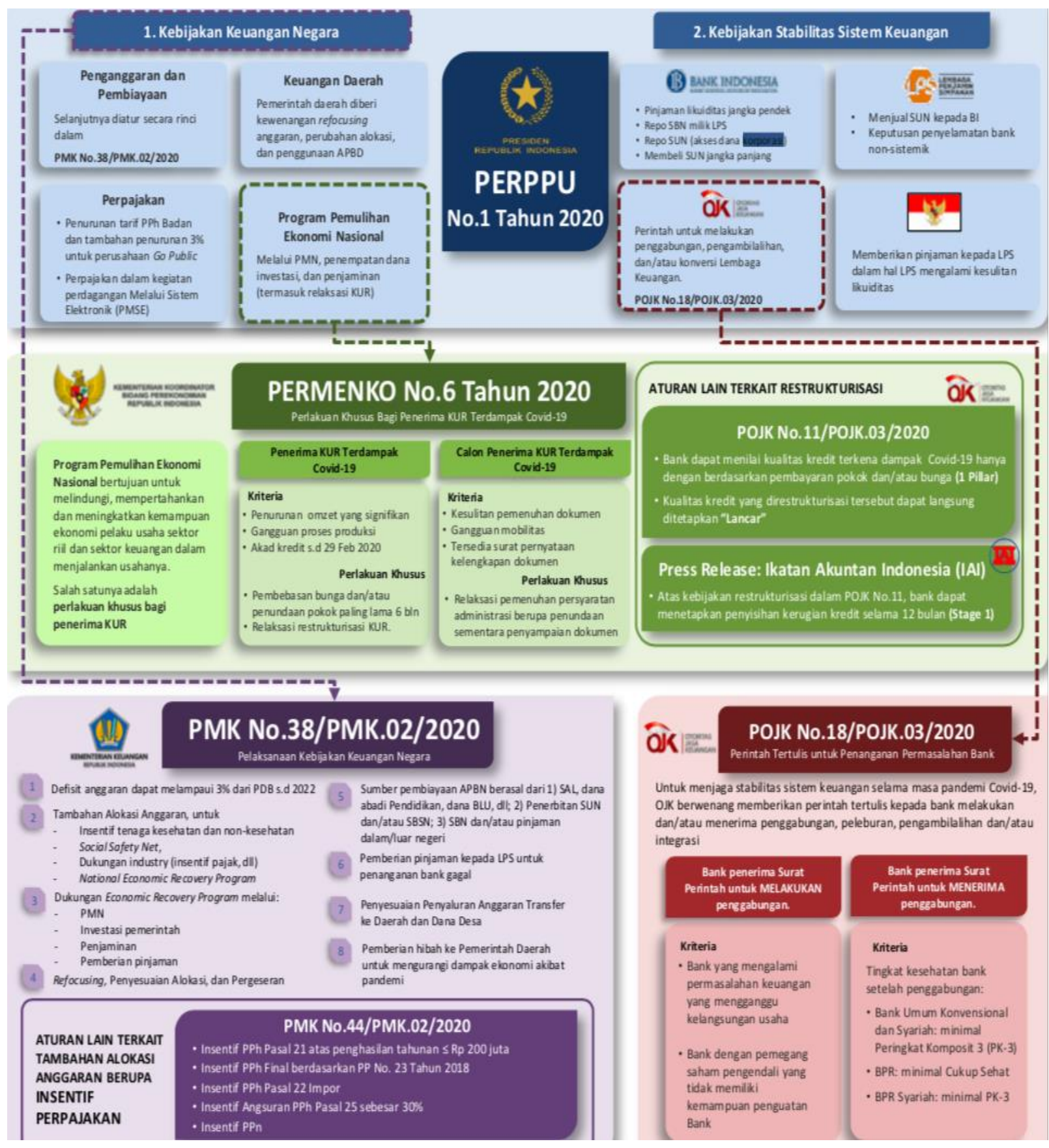

Figure 2. Perppu No.1 the Year 2020 on State Financial Policy and Financial System Stability in The Face of Covid-19.

Source: Kemenkeu

It can be seen that credit restructuring policy for SMEs is one of the country's financial policies and financial system stability in the face of Covid-19. In perppu policy number 1 of 2020 many parties or institutions are involved ranging from the Ministry of Finance, the coordinating ministry of economic recovery, Bank Indonesia, loan guarantor institutions, financial services authorities, banks until down the policy recipients, namely SMEs or borrowers. This credit restructuring policy 
is included in the top-down agreement where the government conducts policies directly to stabilize the country's financial system and economy. The conformity model is a flawed implementation model that assumes that successful implementation depends on the relationship between regional organizations and institutions that are complicated by the policy implementation process, such as cooperation, coordination and supervision become the basis of the results. Implementation with partnerships in the deficit chain will fail. They argue that policies with long causality chains are easily deciphered.

One of Muhammad Khoirudin's debtors (33years old) experienced a decrease of $75 \%$ or more in his business due to the outbreak. Khoirudin has been in the field of furniture and interior decoration since 2008. According to him, as a result of the outbreak, the company spends RP 200 million a month. Before the pandemic, Khoirudin had monthly sales of around Rp 400 million. Therefore, he proposed delaying principal and interest payments by restructuring the credit and extending the credit term. You have to do this because you have to pay 25 employees. After that, I visited the office of PT Bank BRI Indonesia (BRI) (Persero) Tbk to apply for a credit waiver by explaining the business situation and explaining also related installments that are not possible. Khoiruddin received a restructuring with a filing process of approximately 14 days. The tenor for extension of time obtained 12 months with the facility of suspension of principal and interest payments. This program is a government program through the OJK for SMEs affected by Covid-19. The program was extended until March 2022 (Amanda 2020). Based on information from Mr. Khoiruddin, the credit restructuring policy is very helpful for SMEs in continuing their business. Moreover, the condition of covid-19 causes its turnover to run drastically than before. As well as easy and fast submissions make this policy very suitable for SMEs affected by Covid-19.

In addition to Khoirudin, there are also Hatma and Khairi who get help to restructure credit SMEs. Social restrictions carried out by citizens around the world make business activities so sluggish. MSMEs were also hit, ranging from sales and revenue slumping to difficulties in production. The credit that goes on has faltered. How not, the business is hard-earned, especially still have to pay credit installments. Hatma as a debtor MSME actor of PT Bank Mandiri. He has a business processing marine products in the form of knitting, squid, and fish located in Bombana Regency, Southeast Sulawesi. He became a knitting product that was entirely exported to the United States. However, since the outbreak of the coronavirus, his efforts have been hit. The knitting products it supplies cannot be sold because of the cessation of demand from Uncle Sam's country. He also contacted Bank Mandiri to explain the business conditions that did not allow him to pay credit installments. Credit relief was also applied for. Finally, in a relatively quick process, Hatma managed to obtain a credit restructuring. As well as Hatma, Khairi also gets credit relaxation. He is a typical Bandung milk sponge cake trader in Duren Tiga Area, South Jakarta. Once, Khairi watched a show on television that reported the government provided relaxation for one year for MSMEs whose businesses were affected by Covid-19. (Setiawan 2020).

In line with research conducted by Natasya and Hardiningsih (2021), which explained that during the Covid-19 pandemic the provision of social assistance, tax incentives and the expansion of working capital will affect the development of small and medium-sized businesses. Furthermore, according to Soleha (2020) with the government's policy can increase the growth of SMEs in Indonesia so that if SMEs grow it will encourage economic growth in Indonesia. Similar to this according to Novianggie (2021), in his research explained that in general banking NPL is still within controllable limits, because it is still below 5\% overall despite the Covid-19 pandemic conditions and global economic uncertainty. Then the restructuring carried out by banks showed positive results and can encourage the productivity of SMEs. But there are also results that show 
this reconstruction policy has a negative impact on banking. According to Septriawan et al., (2021) based on the results of the best $t$ shows a significance value of $0.00<0.05$ with a coefficient value of -1.260. The value explains that there is a negative influence of restructuring on banking in Indonesia. This means that the high restructuring makes low revenues for banks. In addition, the determination coefficiency showed a value of $0.9450 \mathrm{r} 94.5 \%$. This indicates that $5.5 \%$ of a bank's income is affected variables beyond the variables used.

\section{CONCLUSION AND RECOMMENDATION}

Based on previous discussions, it can be concluded that the implementation of credit restructuring policy for SMEs is already running and used by SMEs. Then based on its implementation this policy is a top-down policy that requires many Institutions to cooperate and decisions derived from the new government regulation is forwarded to other institutions under it until the information is up to and can be felt by SMEs. In the next research can be examined more deeply about the impact obtained from the assistance whether the business can run during the pandemic or even still need further assistance from the Government.

\section{Acknowledgment}

The author's gratitude to Allah SWT, his beloved parents may be given a long life, lecturers Master of Public Administration Universitas Airlangga, and college friends who give each other encouragement.

\section{REFERENCE}

Abdulllah, B., and B. A. Saebani. 2014. Metode Penelitian Ekonomi Islam Muamalah. Bandung: CV Pustaka Setia.

Amanda, Gita. 2020. "UMKM Mengaku Terbantu Dengan Restrukturisasi Kredit OJK." REPUBLIKA.co.id.

Amirullah. 2021. "Gonta-Ganti Istilah Dari PSBB, PPKM Mikro, PPKM Darurat, Apa Bedanya?" TEMPO.CO. https://nasional.tempo.co/read/1478808/gonta-ganti-istilah-dari-psbb-ppkmmikro-ppkm-darurat-apa-bedanya.

CNN. 2021. "Satgas: Kematian Covid-19 Pada Juni Tertinggi Selama Pandemi." CNN Indonesia. https://www.cnnindonesia.com/nasional/20210706101001-20-663693/satgas-kematiancovid-19-pada-juni-tertinggi-selama-pandemi.

Creswell, John W, and J. David Creswell. 2018. Research Design Qualitative, Quantitative, and Mixed Methods Approaches Fifth Edition. SAGE Publications, Inc.

Flynn, Anthony, and Paul Davis. 2016. "Firms' Experience of SME-Friendly Policy and Their Participation and Success in Public Procurement." Journal of Small Business and Enterprise Development 23(3): 616-35.

Gyamerah, Samuel et al. 2021. "The Belt and Road Initiative and East African Small and MediumSized Enterprises: Benefits, Drivers and Particular Sectors." International Journal of Emerging Markets ahead-of-p(ahead-of-print).

Hill, Michael, and Peter Hupe. 2002. Implementing Public Policy: Governance in Theory and in Practice. London: SAGE Publications, Inc.

Horn, Carl Van, and Meter. Donald Van. 1975. The Policy Implementation Process. Beverly Hill: SAGE Publications, Inc.

Kompas. 2021. “Aturan Lengkap PPKM Darurat Jawa-Bali Berlaku 3-20 Juli 2021.” Kompas.com. https://www.kompas.com/tren/read/2021/07/01/114000665/aturan-lengkap-ppkm-daruratjawa-bali-berlaku-3-20-juli-2021 ?page=all.

Lipsky, Michael. 2010. Street-Level Bureaucracy: Dilemmas of the Individual in Public Services. New York: Russell Sage Foundation. 
Marlinah, Lilih. 2021. "Memnfaatkan Insentif Pajak UMKM Dalam Upaya Mendorong Pemuliahan Ekonomi Nasional." Jurnal IKRAITH Ekonomika 4(98): 73-78.

Moleong. 1989. Metodologi Penelitian Kualitatif. Bandung: Remadja Karya CV.

Nasruddin, Rindam, and Islamul Haq. 2020. "Pembatasan Sosial Berskala Besar (PSBB) Dan Masyarakat Berpenghasilan Rendah.” SALAM: Jurnal Sosial dan Budaya Syar-i 7(7).

Natasya, Vina, and Pancawati Hardiningsih. 2021. "Kebijakan Pemerintah Sebagai Solusi Meningkatkan Pengembangan UMKM Di Masa Pandemi." Ekonomis: Journal of Economics and Business 5(1): 141-48.

Nicholas, Caroline, and Michael Fruhmann. 2014. "Small and Medium-Sized Enterprises Policies in Public Procurement: Time for a Rethink?” Journal of Public Procurement 14(3): 328-60.

Novianggie, Vido. 2021. "Optimalisasi Restrukturisasi Kredit Sebagai Relaksasi Kredit Pelaku Umkm Pada Masa Pandemi Corona." Seminar Nasional ADPI Mengabdi Untuk Negeri Pengabdian Masyarakat di Era New Normal 2(2): 65-70.

Pulka, Buba Musa, Azahari Ramli, and Armanurah Mohamad. 2021. "Entrepreneurial Competencies, Entrepreneurial Orientation, Entrepreneurial Network, Government Business Support and SMEs Performance. The Moderating Role of the External Environment." Journal of Small Business and Enterprise Development ahead-of-p(ahead-of-print).

Rosyadi, Slamet et al. 2021. "Barriers of Public Policy Faced by SMEs of Creative Economy in Indonesia." International Journal of Law and Management ahead-of-p(ahead-of-print).

Septriawan, Muhammad Reza, Sri Mulyani, and M Iqbal. 2021. "Pengaruh Rektrukturisasi Kredit Di Masa Pandemi Covid-19 Terhadap Pendapatan Pada Perusahaan Perbankan Yang Terdaftar Di Bursa Efek Indonesia." Ekonomis: Journal of Economics and Business 5(1): 94.

Setiawan, Sakinah Rakhma Diah. 2020. "Cerita UMKM Di Tengah Covid-19, Usaha Berhenti Total Hingga Dapat Keringanan Kredit." Kompas.com. https://money.kompas.com/read/2020/04/17/053800226/cerita-umkm-di-tengah-covid-19usaha-berhenti-total-hingga-dapat-keringanan?page=all.

Soleha, Arin Ramadhiani. 2020. "Kondisi UMKM Masa Pandemi Covid-19 Pada Pertumbuhan Ekonomi Krisis Serta Program Pemulihan Ekonomi Nasional." Jurnal Ekombis 6(2): 16578.

Sukardi. 2003. Metodologi Penelitian Pendidikan Kompetensi Dan Praktiknya. Yogyakarta: Bumi Aksara.

Wahab, S. A. 2012. Analisis Kebijakan, Dari Formulasi Ke Penyusunan Model-Model Implementasi Kebijakan Publik. Jakarta: Bumi Aksara.

Williamson, Oliver. 1975. Market and Hierarchies. New York: Free Press. 